Jurnal Basicedu Volume 4 Nomor 4 Agustus 2020 Halaman 1246-1256
JURNAL BASICEDU
Research \& Learning in Elementary Education
https://jbasic.org/index.php/basicedu

\title{
Pengembangan Media Monopoly Game Pada Pembelajaran Sains Berbasis Kearifan Lokal Siswa Sekolah Dasar
}

\author{
Mansyur Romadhon Putra ${ }^{1}$, Andri Valen ${ }^{2}$, Asep Sukenda Egok ${ }^{3}$ \\ Prodi PGSD, STKIP-PGRI Lubuklinggau, Sumatera Selatan, Indonesia ${ }^{1,2,3}$ \\ E-mail : mansyurromadonputra@ rocketmail.com ${ }^{1}, \underline{\text { valen.andri87@gmail.com }}^{2}$, asep.egok91@gmail.com ${ }^{3}$
}

\begin{abstract}
Abstrak
Tujuan penelitian ini adalah mengembangkan media monopoly game pada pembelajaran Sains berbasis kearifan lokal siswa sekolah dasar. Berdasarkan hasil uji kevalidan media monopoly game pada pembelajaran Sains berbasis kearifan lokal termasuk pada kategori sangat baik yang berarti valid pada validasi ketiga yang mana media layak diuji cobakan dengan nilai rata-rata 4,1 oleh ahli media dari 9 indikator termasuk kategori valid untuk digunakan, pada validasi kedua dengan nilai rata-rata 4,55 oleh ahli materi dari 9 indikator termasuk kategori sangat valid untuk digunakan dan pada validasi kesatu yaitu ahli bahasa dengan nilai 4,0 dari 8 indikator termasuk kategori valid untuk digunakan. Tingkat kepraktisan media monopoly pada pembelajaran Sains berbasis kearifan lokal didapat melalui wawancara siswa dari 6 orang siswa, dari 9 pernyataan yang diajukan kepada siswa mendapat jawaban positif dimana siswa senang belajar dengan menggunakan media monopoly game pada pembelajaran Sains berbasis kearifan lokal dan siswa lebih mudah memahami materi yang disampaikan. Berdasarkan hasil penelitian dan pengembangan media monopoly game berbasis kearifan lokal diketahui bahwa media telah dapat digunakan dalam pembelajaran. Media ini dapat membantu siswa dan guru di dalam pembelajaran Sains khususnya materi penyesuaian diri makhluk hidup dan lingkungannya.

Kata kunci: monopoly game, pembelajaran sains,kearifan lokal.
\end{abstract}

\begin{abstract}
The purpose of this study was to develop monopoly game media in learning Science based on local wisdom of elementary school students. Based on the results of the validity test of the game monopoly media on local wisdom based Science learning, it is included in the very good category which means that it is valid in the third validation where the media is feasible to be tested with average value of 4,1 by media experts from 9 indicators including the category valid for use, in the second validation with average value of 4,55 by material experts from 9 indicators including the very valid category to use and in the first validation, namely linguists with average value of 4,0 of 8 indicators including the category valid to use. The practicality level of monopoly media in local wisdom based Science learning is obtained through student interviews from 6 students, from 9 statements submitted to students, they get positive answers where students like to learn using monopoly game media in local wisdom based Science learning and students understand the material easier that was delivered. Based on the results of research and development of local wisdom based monopoly game media, it is known that the media can be used in learning. This media can help students and teachers in learning $s$ Science, especially material for the adjustment of living things and their environment.

Keywords: monopoly game, science learning, local wisdom.
\end{abstract}

Copyright (c) 2020 Mansyur Romadhon Putra, Andri Valen, Asep Sukenda Egok

Corresponding author :

Address : Jalan Pioner No. 110 Kel. Majapahit

Email : valen.andri87@gmail.com

ISSN 2580-3735 (Media Cetak)

Phone : 082176684535

ISSN 2580-1147 (Media Online)

DOI: https://doi.org/10.31004/basicedu.v4i4.529 
1247 Pengembangan Media Monopoly Game Pada Pembelajaran Sains Berbasis Kearifan Lokal Siswa Sekolah Dasar - Mansyur Romadhon Putra, Andri Valen dan Asep Sukenda Egok

DOI: https://doi.org/10.31004/basicedu.v4i4.529

\section{PENDAHULUAN}

Pembelajaran pada hakikatnya adalah suatu proses dimana terjadinya interaksi edukatif antara guru dan siswa. Ilmu Pengetahuan Alam atau biasa disebut Sains merupakan konsep pembelajaran alam dan mempunyai hubungan yang sangat luas terkait dengan kehidupan manusia dan alam. Disamping itu juga, Sains merupakan ilmu yang bersifat empiris dan membahas tentang fakta dan gejala-gejala alam. Oleh karena fakta dan gejalagejala alam yang terjadi menjadikan pembelajaran Sains, tidak hanya bersifat lisan, tetapi juga bersifat kenyataan.

Sains erat kaitannya dengan cara mencari tahu tentang alam secara sistematis, sehingga Sains bukan hanya penguasaan kumpulan sistematis. Sains bukan hanya penguasaan kumpulan pengetahuan yang berupa fakta-fakta, konsepkonsep atau prinsip-prinsip saja, tetapi juga merupakan suatu proses penemuan (Sulistyorini, 2007).

Sains merupakan ilmu pengetahuan khusus yang menuntut siswa untuk melakukan observasi, eksperimentasi, penyimpulan, penyusunan teori dan proses lainnya. Pembelajaran Sains di sekolah dasar dihadapkan pada berbagai masalah seperti fasilitas, media dan dana, sehingga dalam penerapannya kurang efektif. (Valen, 2020) menyatakan bahwa peranan guru sebagai pendidik sangat besar pengaruhnya terhadap perubahan kemampuan berpikir siswa. Guru memiliki tugas untuk merencanakan pembelajaran, melaksanakan kegiatan pembelajaran, serta melakukan penilaian terhadap proses dan hasil belajar siswa.
Ada banyak faktor yang mempengaruhi tercapainya tujuan pembelajaran, salah satunya adalah faktor media pembelajaran. Penggunaan media pembelajaran akan membantu guru menyampaikan pesan pembelajaran kepada para siswanya. Menurut (Siwi Pawestri Apriliani, 2020) media dapat memudahkan guru dalam proses pembelajaran dan siswa akan lebih tertarik dalam mengikuti proses dalam belajar. Selain itu, penggunaan media pembelajaran yang tepat membuat proses pembelajaran lebih efisien. Penggunaan media pembelajaran yang tepat, dapat membantu mengurangi masalah pembelajaran yang terjadi.

Pemilihan media pembelajaran yang tepat harus dipilih berdasarkan karakteristik peserta belajar, karakteristik mata pelajaran, dan lain sebagainya. Media pembelajaran akan berfungsi optimal jika sesuai dengan sasaran. Pembelajaran Sains di sekolah dasar memerlukan sebuah media sebagai sarana pendukung pembelajaran. Media pembelajaran monopoli belum tersedia atau belum digunakan di Sekolah Dasar Kota Lubuklinggau. Media ini merupakan media pembelajaran berbentuk permainan yang dimainkan secara kelompok atau lebih dari satu orang.

Konsep pengembangan media ini memperhatikan karakteristik siswa usia sekolah dasar yang suka bermain. Menurut Piaget (Diana, 2012) permainan sebagai suatu media yang dapat meningkatkan perkembangan kognitif anak-anak. Permainan memberikan ruang bagi anak mempraktikkan kompetensi-kompetensi dan keterampilan yang diperlukan dengan cara yang santai dan menyenangkan. 
1248 Pengembangan Media Monopoly Game Pada Pembelajaran Sains Berbasis Kearifan Lokal Siswa Sekolah Dasar - Mansyur Romadhon Putra, Andri Valen dan Asep Sukenda Egok

DOI: https://doi.org/10.31004/basicedu.v4i4.529

Kegiatan belajar yang hanya menggunakan buku pegangan utama yang bersumber dari BSE dan satu buku pendamping. Penggunaan media pembelajaran yang minim, akan menjadi salah satu faktor penghambat dalam penyampaian pesan pembelajaran yang disampaikan oleh guru. Selain itu, metode konvensional yang diterapkan guru akan membuat siswa merasa bosan sehingga sulit bagi siswa dalam menerima materi pelajaran.

Berdasarkan paparan yang dijelaskan di atas, maka diperlukan media yang tepat untuk membantu guru menyampaikan materi pelajaran pada siswa, khusus pembelajaran Sains. Media yang tepat sesuai dengan karakteristik siswa sekolah dasar adalah media yang berbentuk permainan. Oleh karena itu, peneliti memilih untuk mengembangkan media permainan berbentuk monopoli dengan materi penyesuaian diri makhluk hidup dengan lingkungannya untuk siswa kelas $\mathrm{V}$ SD di Kota Lubuklinggau.

Berdasarkan hasil penelitian (Elisabeth Irma, 2018) yang berjudul Permainan Monopoli Berbasis Problem Based Learning untuk Meningkatkan Keterampilan Berpikir Kritis dapat diketahui bahwa seluruh tes dan hasil penelitiannya menunjukkan media pembelajaran monopoli berbasis PBL berpengaruh positif terhadap kemampuan berpikir kritis siswa, dengan signifikansi $\mathrm{p}<0,05$.

\section{METODE}

Metode penelitian yang akan peneliti gunakan adalah Reseach and Development (R\&D) menggunakan Borg \& Gall yang terdiri dari 9 langkah pengembangan, terdiri dari:
1. Penelitian dan Pengumpulan Informasi Awal

Peneliti melakukan wawancara kepada guru mata pelajaran bidang IPA kelas $\mathrm{V}$ di beberapa sekolah dasar Kota Lubuklinggau.

2. Melakukan Perencanaan

Peneliti melakukan perencanaan untuk menyelesaikan masalah yang terjadi dilapangan. Dimulai dengan mencari referensi tentang karakteristik siswa kelas $\mathrm{V}$ $\mathrm{SD}$, lalu dilanjutkan dengan mencari referensi tentang pelajaran IPA kelas V SD. Setelah mendapatkan referensi, peneliti akan menentukan subbab yang cocok menurut peneliti untuk dibuat medianya, setelah menentukannya, peneliti akan membuat desain awal rancangan media pembelajaran monopoli. Pembuatan desain menggunakan aplikasi Corel Draw X7.

3. Pengembangan Produk Awal

Peneliti mengembangkan bentuk awal produk. Konsep dari pengembangan awal ini berdasarkan hasil data atau informasi yang didapat melalui wawancara dan observasi di lapangan.

4. Uji Coba Lapangan Awal

Peneliti melakukan uji coba langsung media yang telah dihasilkan di lapangan. Uji coba yang akan dilakukan dengan skala kecil. Uji coba lapangan awal ini dilakukan oleh 4 siswa SD kelas V. Hasil data yang diperoleh setelah melakukan uji coba awal tersebut akan dijadikan masukan untuk melakukan perbaikan produk awal. 
1249 Pengembangan Media Monopoly Game Pada Pembelajaran Sains Berbasis Kearifan Lokal Siswa Sekolah Dasar - Mansyur Romadhon Putra, Andri Valen dan Asep Sukenda Egok

DOI: https://doi.org/10.31004/basicedu.v4i4.529

5. Revisi Produk Awal

Peneliti melakukan revisi berdasarkan hasil yang diperoleh dari uji coba lapangan awal. Data yang didapatkan berdasarkan hasil uji coba awal akan digunakan sebagai dasar untuk perbaikan produk agar yang dikembangkan menjadi layak untuk diuji cobakan kembali pada uji coba lapangan utama.

6. Uji Coba Lapangan Utama

Uji coba lapangan utama merupakan proses uji coba yang kedua kalinya. Pada tahap ini, peneliti akan melakukan uji coba kepada 8 siswa kelas 5 SD yang dibagi menjadi 2 kelompok. Data yang diperoleh pada uji coba lapangan utama menggunakan metode angket. Hasil data yang terkumpul akan digunakan untuk melakukan perbaikan kembali terhadap media monopoli.

7. Revisi Produk Hasil Uji Coba Lapangan Revisi dilakukan berdasarkan hasil uji coba lapangan utama. Data yang didapatkan melalui metode angket, menjadi dasar perbaikan dari media yang dikembangkan. Hasil dari perbaikan media akan digunakan pada uji coba lapangan operasional.

8. Uji Lapangan Operasional

Uji lapangan operasional merupakan uji coba terakhir pada penelitian ini. Uji lapangan operasional akan dilakukan dalam skala besar, dimana melibatkan 20 siswa kelas 5 yang dibagi dalam 5 kelompok. Selain melakukan uji lapangan operasional, peneliti juga akan melakukan pengamatan dan pengumpulan data hasil uji lapangan menggunakan metode angket.

9. Revisi Produk Akhir

Peneliti melakukan revisi produk untuk terakhir kalinya. Revisi produk menggunakan data hasil analisis uji coba lapangan operasional. Hasil dari revisi produk diharapkan sudah layak untuk digunakan dan disebarluaskan.

Penelitian ini menggunakan teknik analisis data kualitatif dan kuantitatif berupa presentase. Data kualitatif ini diperoleh dari validasi ahli materi pembelajaran, ahli media pembelajaran dan ahli praktisi (guru) yang berupa masukan dan saran untuk melakukan revisi terhadap pengembangan media.

\section{HASIL DAN PEMBAHASAN}

Media monopoly game pada pembelajaran Sains berbasis kearifan lokal yang dikembangkan dibuat dengan menggunakan software Corel Draw X7 sebagai salah satu aplikasi pembuat dan pengedit grafik. Terdapat beberapa komponen monopoly game pada pembelajaran Sains berbasis kearifan lokal yaitu.

1. Papan Monopoly Game Pada Pembelajaran Sains Berbasis Kearifan Lokal

Papan monopoli game pada pembelajaran Sains berbasis kearifan lokal berbeda dari papan permainan monopoli yang asli. Ukuran papan monopoly game pada pembelajaran Sains berbasis kearifan lokal berbentuk cetakan dengan ukuran $60 \times 60 \mathrm{~cm}$. Perbedaan mendasar dari papan monopoly game pada pembelajaran Sains berbasis kearifan lokal dengan monopoli 
1250 Pengembangan Media Monopoly Game Pada Pembelajaran Sains Berbasis Kearifan Lokal Siswa Sekolah Dasar - Mansyur Romadhon Putra, Andri Valen dan Asep Sukenda Egok

DOI: https://doi.org/10.31004/basicedu.v4i4.529

yang asli terletak pada jumlah petak dan didalam papan monopoly game pada pembelajaran Sains berbasis kearifan lokal terdapat gambar-gambar yang dapat menjelaskan suatu konsep atau materi pada pembelajaran Sains yaitu tentang penyesuaian diri makluk hidup dan lingkungan serta dipadukan dengan kearifan lokal kota Lubuklinggau yang digunakan sesuai dengan yang akan diajarkan di Sekolah.

2. Dadu dan Biji

Berbeda dari permainan monopoli asli yang menggunakan 2 dadu, monopoli game pada pembelajaran Sains berbasis kearifan lokal menggunakan 1 dadu dalam permainannya. Penggunaan 1 dadu disesuaikan dengan jumlah petak yang sedikit. Sedangkan setiap pemain diwakili oleh pion catur yang menandakan tempat berhentinya pemain pada petak.

3. Peraturan Monopoly Game Pada Pembelajaran Sains Berbasis Kearifan Lokal

Peraturan monopoly game pada pembelajaran Sains berbasis kearifan lokal juga sangat berbeda dari peraturan pada permainan monopoli asli. Berikut ini berapa perbedaan dari peraturan monopoly game pada pembelajaran Sains berbasis kearifan lokal:

a. Alat Pembayaran

Permainan monopoli asli menggunakan uang sebagai alat pembayaran untuk jual beli. Sedangkan di dalam monopoly game pada pembelajaran Sains berbasis kearifan lokal penggunaan uang digantikan dengan penggunaan poin.

b. Kartu Sertifikat Tanah
Kartu sertifikat tanah monopoly game pada pembelajaran Sains berbasis kearifan lokal dilengkapi dengan pertanyaan seputar materi yang diajarkan. Jika pemain berhenti pada sebuah petak kosong maka pemain harus menjawab pertanyaan yang berada pada petak tanah. Pemain yang berhasil menjawab dengan benar maka berhak memperoleh poin dari bank sesuai yang tertera pada gambar dan pemain berhak membeli tanah dengan harga yang telah ditentukan dari poin yang didapatkan dari bank.

c. Kartu Kesempatan Umum

Permainan monopoli identik dengan adanya dua kartu yang berada ditengah papan monopoli. Kartu kesempatan merupakan salah satu kartu yang berwarna merah muda dan biasanya berisi perintah. Perbedaan kartu kesempatan pada monopoly game pada pembelajaran Sains berbasis kearifan lokal terletak pada isinya yaitu terdapat delapan kartu masing-masing terdiri dari: 5 kartu perintah untuk berdiskusi, kartu perintah untuk maju beberapa langkah, dan 1 kartu keberuntungan.

d. Kartu Pengetahuan Umum

Kartu pengetahuan umum merupakan modifikasi dari kartu dana umum yang terdapat di dalam monopoli asli. Kartu pengetahuan umum berisi informasiinformasi berkenaan dengan kearifan Kota Lubuklinggau dan juga perintah maju mundur. 
1251 Pengembangan Media Monopoly Game Pada Pembelajaran Sains Berbasis Kearifan Lokal Siswa Sekolah Dasar - Mansyur Romadhon Putra, Andri Valen dan Asep Sukenda Egok

DOI: https://doi.org/10.31004/basicedu.v4i4.529

\section{Validasi Ahli}

Validasi ahli bertujuan untuk mengetahui layak atau tidaknya sebuah instrumen dan perangkat pembelajaran sebelum diujicobakan. Validasi ahli meliputi: 1) validasi bahasa, 2) validasi media, 3) validasi materi. Berikut akan dijelaskan beberapa tahap tersebut:

a. Ahli Bahasa

Ahli bahasa yang direkomendasikan sebagai validator, memberikan penilaian pada komponen kebahasaan. Pada lembar validasi bahasa terdapat 8 pernyataan. Adapun hasil penilaian validator bahasa terhadap pengembangan media monopoly game pada pembelajaran Sains berbasis kearifan lokal diperoleh nilai rata-rata 4,0 yang berarti valid dari segi bahasa. Hal ini layak untuk diuji cobakan dengan revisi sesuai saran.

b. Ahli Materi

Ahli materi yang direkomendasikan sebagai validator memberikan penilaian terhadap cakupan materi. Pada lembar validasi materi terdapat 9 pernyataan. Adapun hasil penilaian validator materi terhadap pengembangan media monopoly game pada pembelajaran Sains berbasis kearifan lokal diperoleh nilai rata-rata 4,55 yang berarti valid dari segi materi. Hal ini layak untuk diuji cobakan dengan revisi sesuai saran.

c. Ahli Media

Ahli media yang direkomendasikan sebagai validator memberikan penilaian terhadap komponen kebahasaan. Pada lembar validasi media terdapat 9 pernyataan. Adapun hasil penilaian validator media terhadap pengembangan media monopoly game pada pembelajaran Sains berbasis kearifan lokal diperoleh nilai rata-rata 4,1 yang berarti valid dari segi media. Hal ini layak untuk diuji cobakan dengan revisi sesuai saran.

d. Rekapitulasi Penilaian Validator

Adapun hasil keseluruhan penilaian media monopoly game pada pembelajaran Sains berbasis kearifan lokal dari ketiga validator yaitu: validator bahasa, validator materi dan validator media terhadap pengembangan media monopoly game pada pembelajaran berbasis kearifan lokal dapat dilihat pada tabel 1 berikut:

Tabel 1. Hasil Penilaian Seluruh Validator

\begin{tabular}{|c|l|c|c|c|c|}
\hline No & \multicolumn{1}{|c|}{ Nama Validator } & $\begin{array}{c}\text { Jumlah butir } \\
\text { pernyataan }\end{array}$ & $\begin{array}{c}\text { Skor yang di } \\
\text { peroleh }\end{array}$ & Rata-rata skor & Kriteria \\
\hline 1. & Dr. Rusmana Dewi, M.Pd. & 8 & 32 & 4,0 & Valid \\
\hline 2. & Zico Fachrurozi, M.Pd.Si. & 9 & 41 & 4,55 & Sangat Valid \\
\hline 3. & Dr. Dodik Mulyono, M.Pd. & 15 & 61 & 4,1 & Valid \\
\hline \multicolumn{2}{r|}{ Total } & 32 & 134 & 4,2 & Sangat Valid \\
\hline
\end{tabular}


1252 Pengembangan Media Monopoly Game Pada Pembelajaran Sains Berbasis Kearifan Lokal Siswa Sekolah Dasar - Mansyur Romadhon Putra, Andri Valen dan Asep Sukenda Egok

DOI: https://doi.org/10.31004/basicedu.v4i4.529

\section{Revisi Produk}

Revisi bertujuan untuk memperbaiki kekurangan dari produk berdasarkan nilai, kritik, dan juga saran dari validator sebelum diuji cobakan. Setelah direvisi maka media pembelajaran monopoly game pada pembelajaran Sains berbasis kearifan lokal dinyatakan layak dan siap untuk diujicobakan.

\section{Uji Coba Perorangan}

Uji coba perorangan ini bertujuan untuk mengetahui hambatan dan juga kekurangan dari media yang dikembangkan sebagai acuan untuk mengadakan revisi. Uji coba perorangan dilakukan pada dua orang anak SD kelas V dan kemudian diamati secara langsung oleh peneliti.

\section{Uji Coba Kelompok Kecil}

a. Penyajian Data Uji Coba Kelompok Kecil

Uji coba kelompok kecil merupakan uji coba poduk tahap kedua yang dilakukan pada siswa kelas V SD Kota Lubuklinggau yang sudah menyelesaikan materi penyesuaian diri makhluk hidup dan lingkungan sebanyak 6 orang.

b. Analisis Data Uji Coba Kelompok Kecil

1) Analisis Data Respon Siswa

Data hasil respon siswa pada saat uji coba kelompok kecil dapat diketahui bahwa terdapat respon yang sangat positif dari siswa terhadap media monopoly game pada pembelajaran Sains berbasis kearifan lokal. Hal ini dibuktikan dengan perolehan persentase total respon yaitu $100 \%$. Hal ini sesuai dengan kriteria respon yang sangat positif yang memiliki nilai $\geq 85 \%$ (Zaahirah, Wijhatuz, 2014).

2) Analisis Kepraktisan Media

Pelaksanaan kepraktisan media dilakukan dalam uji coba small group (kelompok kecil). Pelaksanaan uji kepraktisan kelompok kecil yang terdiri dari 6 siswa dengan kemampuan tinggi, sedang dan rendah yang dipilih sesuai prestasi siswa di kelas. Sebelum diberi lembar kepraktisan, enam orang siswa terlebih dahulu diminta untuk memainkan media monopoly game pada pembelajaran Sains berbasis Kearifan Lokal secara mandiri dengan dibimbing peneliti selama 30 menit. Setelah itu masing-masing siswa diberi lembar kepraktisan yang terdiri dari 9 butir pertanyaan. Siswa dapat memberi jawaban terhadap pernyataan dengan memberikan tanda checklist $(\sqrt{ })$ pada angket kepraktisan siswa yang terdiri dari "ya" atau "tidak", yang bertujuan untuk mengetahui kepraktisan media monopoly game pada pembelajaran Sains berbasis Kearifan Lokal yang dikembangkan.

Berdasarkan hasil angket kelompok kecil diperoleh skor rata-rata 94.4, dapat disimpulkan bahwa respon siswa terhadap media monopoly game pada pembelajaran Sains berbasis kearifan lokal materi penyesuaian diri dan lingkungannya adalah sangat praktis. 
1253 Pengembangan Media Monopoly Game Pada Pembelajaran Sains Berbasis Kearifan Lokal Siswa Sekolah Dasar - Mansyur Romadhon Putra, Andri Valen dan Asep Sukenda Egok

DOI: https://doi.org/10.31004/basicedu.v4i4.529

Tabel 2. Uji Coba Kelompok Kecil

\begin{tabular}{|c|c|c|c|c|c|c|c|c|c|c|c|c|}
\hline \multirow{2}{*}{ Responden } & \multicolumn{9}{|c|}{ Item } & \multirow{2}{*}{$\begin{array}{c}\text { Skor } \\
\text { Maksimal }\end{array}$} & \multirow{2}{*}{$\begin{array}{l}\text { Skor yang } \\
\text { diperoleh }\end{array}$} & \multirow{2}{*}{$\begin{array}{l}\text { Skor rata- } \\
\text { rata }\end{array}$} \\
\hline & 1 & 2 & 3 & 4 & 5 & 6 & 7 & 8 & 9 & & & \\
\hline Galih Saputra & 1 & 1 & 1 & 1 & 1 & 1 & 1 & 1 & 1 & 9 & 9 & 100 \\
\hline Yufi Desta L & 1 & 1 & 1 & 1 & 1 & 0 & 1 & 1 & 1 & 9 & 8 & 88.8 \\
\hline Yuli Anggara & 1 & 1 & 1 & 1 & 1 & 1 & 0 & 1 & 1 & 9 & 8 & 88.8 \\
\hline Nayra Gustika & 1 & 1 & 1 & 1 & 1 & 1 & 1 & 1 & 1 & 9 & 9 & 100 \\
\hline Rena Mustika & 1 & 1 & 1 & 0 & 1 & 1 & 1 & 1 & 1 & 9 & 8 & 88.8 \\
\hline Anggi Klaudia & 1 & 1 & 1 & 1 & 1 & 1 & 1 & 1 & 1 & 9 & 9 & 100 \\
\hline \multicolumn{11}{|c|}{ Jumlah Keseluruhan } & 51 & 566.4 \\
\hline \multicolumn{11}{|c|}{ Skor rata-rata keseluruhan } & & 94.4 \\
\hline \multicolumn{11}{|c|}{ Kategori } & \multicolumn{2}{|c|}{ Sangat Praktis } \\
\hline
\end{tabular}

Berdasarkan uraian hasil penelitian diperoleh produk penelitian berupa media monopoly game pada pembelajaran berbasis kearifan lokal yang membahas materi penyesuaian diri dan lingkungannya. Media monopoly game pada pembelajaran berbasis kearifan lokal ini dikembangkan dengan menggunakan model pengembangan Borg \& Gall. Pembahasan disajikan dalam dua bagian, yaitu: 1) proses pengembangan monopoly game pada pembelajaran berbasis kearifan lokal materi penyesuaian diri dan lingkungannya, 2) valid dan praktis dari media monopoly game pada pembelajaran berbasis kearifan lokal materi penyesuaian diri dan lingkungannya.

1. Proses Pengembangan Media Monopoly Game Pada Pembelajaran Berbasis Kearifan Lokal

Tahap pendefinisian (define) ada beberapa hal yang peneliti lakukan yaitu: analisis awal, analisis siswa, analisis tugas, analisis konsep dan perumusan tugas pembelajaran. Pada analisis awal diperoleh bahwa kurikulum yang digunakan siswa kelas II SDN 26 Lubuklinggau yaitu Kurikulum Tingkat Satuan Pendidikan (KTSP), metode pembelajaran juga berpusat pada guru, selain itu guru belum menggunakan media pembelajaran yang membuat siswa menjadi aktif, mandiri dan berfikir secara kreatif dalam menemukan dan mengembangkan pengetahuan dengan tujuan agar siswa dapat memahami materi pelajaran dengan baik.

Pada tahap analisis siswa kelas V SDN 26 Lubuklinggau rata-rata berusia 6 atau 7 samapai 12 tahun, kemampuan siswa seperti pada umumnya yaitu tinggi, sedang dan rendah. Siswa belum mampu bersifat abstrak, memiliki rasa ingin tahu yang tinggi dan siswa kurang memahami materi sehingga siswa bersifat pasif karena hanya mendengarkan penjelasan guru.

Pada tahap analisis tugas peneliti menyusun kebutuhan media yang dapat dijadikan dasar membuat media. Pada tahap analisis konsep, konsep-konsep yang telah ada dan disusun secara sistematis sehingga membentuk peta konsep. Kemudian hasil analisis tugas dan konsep dijadikan dasar dalam merumuskan tujuan pembelajaran. 
1254 Pengembangan Media Monopoly Game Pada Pembelajaran Sains Berbasis Kearifan Lokal Siswa Sekolah Dasar - Mansyur Romadhon Putra, Andri Valen dan Asep Sukenda Egok

DOI: https://doi.org/10.31004/basicedu.v4i4.529

Tes acuan patokan dapat dirumuskan setelah tujuan pembelajaran disusun. Pada tes acuan patokan soal-soal yang disajikan adalah soalsoal esai dan soal cerita yang diangkat dari materi yang telah dibahas. Pada pemilihan media, media monopoly game pada pembelajaran berbasis kearifan lokal yang digunakan sebagai sarana menyampaikan informasi/pesan. Tahap pemilihan format disusun berdasarkan aspek pengembangan media agar fungsi media dapat mencapai tujuan pembelajaran. Tahap yang terakhir yaitu tahap desain awal media pembelajaran, dalam menyusun media pembelajaran dua hal yang menjadi pertimbangan yaitu: materi yang sesuai dengan media monopoly game berbasis kearifan lokal dan struktur dari media. Selaras dengan pendapat Indriana, 2011 media pembelajaran adalah segala sesuatu yang berbentuk fisik untuk menyampaikan pesan sesuai dengan materi dan tujuan dari pembelajaran.

2. Valid dan praktis dari Media Monopoly Game Berbasis Kearifan Lokal

Media yang baik digunakan yaitu media yang bersifat konkret dan dapat mainkan oleh siswa. Berdasarkan hasil analisis yang diperoleh peneliti perlu mengembangan media pembelajaran pada materi penyesuaian diri dan lingkungannya agar siswa dapat belajar secara aktif, mandiri dan kreatif dalam menemukan pengetahuan baru sehingga siswa tersebut dapat memahami materi dengan baik. Tahap pembuatan instrumen, peneliti membuat 2 instrumen penilaian media yaitu instrumen untuk menilai kevalidan media dan instrument untuk menilai kepraktisan media.

3. Tahap Pengembangan.

Hal-hal yang dilakukan adalah mengembangkan media, validasi media, revisi media dan uji kepraktisan. Pada tahap pengembangan media, hal yang dilakukan peneliti adalah pembuatan media yang telah dirancang berdasarkan analisis pada tahap pendefinisian (define). Media disusun dengan menggunakan bahan yang aman dan warna yang cerah. monopoly game pada pembelajaran Sains berbasis kearifan lokal ini terbuat dari papan dan dipadukan dengan kertas foto, sehingga media ini aman digunakan untuk siswa, tidak mudah rusak dan media ini bisa digunakan untuk materi lain selain materi penyesuaian diri dan lingkungannya. Hasil rancangan media ini divalidasi oleh tiga ahli yaitu: ahli bahasa, ahli materi dan ahli media. Validasi dilakukan untuk mengetahui kevalidan media monopoly game pada pembelajaran Sains berbasis kearifan lokal. Berdasarkan hasil analisis penelitian kevalidan media oleh para ahli mendapatkan skor rata-rata 4.2 yang dikategorikan sangat valid dan layak untuk diuji cobakan dengan beberapa perbaikan sesuai saran dari ketiga para ahli.

Setelah media monopoly game pada pembelajaran Sains berbasis kearifan lokal direvisi selanjutnya diuji cobakan 
1255 Pengembangan Media Monopoly Game Pada Pembelajaran Sains Berbasis Kearifan Lokal Siswa Sekolah Dasar - Mansyur Romadhon Putra, Andri Valen dan Asep Sukenda Egok

DOI: https://doi.org/10.31004/basicedu.v4i4.529

kelompok kecil yang terdiri dari 6 siswa kelas V SDN 26 Lubuklinggau untuk mengetahui kepraktisan media monopoly game pada pembelajaran Sains berbasis kearifan lokal yang dikembangkan. Tahap uji coba kelompok kecil yang terdiri dari 6 siswa, hasil analisis data lembar kepraktisan siswa sebanyak 9 pernyataan dengan rata-rata skor sebesar 94.4 dengan kriteria sangat praktis. Sehingga dapat disimpulkan bahwa, pengembangan media monopoly game pada pembelajaran Sains berbasis kearifan lokal dalam pembelajaran membuat siswa lebih aktif dalam belajar, antusias dalam mengerjakan soal, menarik perhatian siswa dan membuat siswa mudah memahami materi yang diajarkan. Hal ini sesuai dengan pendapat Arsyad, 2006 media pembelajaran merupakan segala sesuatu yang dapat menyampaikan pesan, sehingga terjadi lingkungan belajar yang menyenangkan, aktif, kondusif, efektif dan efisien.

\section{SIMPULAN}

Berdasarkan hasil uji kevalidan media monopoly game pada pembelajaran Sains berbasis kearifan lokal termasuk pada kategori sangat baik yang berarti valid pada validasi ketiga yang mana media layak diuji cobakan dengan melakukan beberapa revisi, dengan nilai persentase $82 \%$ oleh ahli media dari 9 indikator termasuk kategori valid untuk digunakan, pada validasi kedua dengan nilai persentase $94 \%$ oleh ahli materi dari 9 indikator termasuk kategori sangat valid untuk digunakan dan pada validasi ketiga yaitu ahli bahasa dengan nilai persentase $80 \%$ dari 8 indikator termasuk kategori valid untuk digunakan. Sehingga dapat disimpulkan bahwa persentase dari ketiga ahli tersebut dalam kategori sangat valid, sehingga dapat diuji coba dengan sedikit revisi.

Tingkat kepraktisan media monopoly pada pembelajaran Sains berbasis kearifan lokal didapat melalui wawancara siswa dari 6 orang siswa dengan menggunakan 9 pernyataan yang diberikan untuk mengetahui jawaban ataupun respon dari siswa. Dari pernyataan yang diajukan kepada siswa mendapat jawaban positif dimana siswa senang berlajar dengan menggunakan Media monopoly game pada pembelajaran Sains berbasis kearifan lokal dan siswa lebih mudah memahami materi yang disampaikan.

Berdasarkan hasil penelitian dan pengembangan media monopoly game pada pembelajaran Sains berbasis kerifan lokal diketahui bahwa media telah dapat digunakan dalam pembelajaran. Media ini dapat membantu siswa dan guru di dalam pembelajaran Sains khususnya materi penyesuaian diri makhluk hidup dan lingkungannya.

\section{DAFTAR PUSTAKA}

Arsyad, A. (2006). Media Pembelajaran. Raja Grafindo Persada.

Diana, M. (2012). Psikologi Bermain Anak Usia Dini. Kencana Prenada Media Group.

Elisabeth Irma, N. D. (2018). Permainan Monopoli Berbasis Problem Based Learning Untuk 
1256 Pengembangan Media Monopoly Game Pada Pembelajaran Sains Berbasis Kearifan Lokal Siswa Sekolah Dasar - Mansyur Romadhon Putra, Andri Valen dan Asep Sukenda Egok

DOI: https://doi.org/10.31004/basicedu.v4i4.529

Meningkatkan Kemampuan Berpikir Kritis. Jurnal Pendidikan Dan Kebudayaan Missio, 10(1), 59-69.

Indriana, D. (2011). Ragam Alat Bantu Media Pengajaran: Mengenal, Merancang dan Mempraktikkannya. Diva Press.

Siwi Pawestri Apriliani, E. H. R. (2020). Pengembangan Media Pembelajaran Buku Cerita Bergambar untuk Meningkatkan Minat Membaca Siswa Sekolah Dasa. Basicedu, 4(4), 994-1003.

Sulistyorini. (2007). Media Pembelajaran IPA Sekolah Dasar dan Penerapannya dalam KTSP. Tiara Wacana.

Valen, A. (2020). Analisis Pemahaman dan Kemampuan Guru Menyusun Soal Mid Semester Mata Pelajaran IPS Sekolah Dasar. Basicedu, 4(4), 1084-1097.

Zaahirah, Wijhatuz, K. (2014). Penerapan Model Pembelajaran Kooperatif Tipe Two Stay Two Stray Pada Materi Luas Permukaan Balok. Jurnal Ilmiah Pendidikan Matetatika, 3(3), 252-258. 